\title{
Fixed point theorems for multivalued generalized contractions of rational type in complete metric spaces
}

\section{ANCA M. OPREA}

\section{ABSTRACT.}

The purpose of this paper is to present some fixed point theorems for multivalued contractions of rational type. We extend the results of I. Cabrera, J. Harjani and K. Sadarangan, A fixed point theorem for contractions of rational type in partially ordered metric spaces, Annali dellUniversita di Ferrara, DOI 10.1007/s11565-013-0176-x, to the case of multivalued operators.

\section{REFERENCES}

[1] Cabrera, I., Harjani, J. and Sadarangani, K., A fixed point theorem for contractions of rational type in partially ordered metric spaces, Annali dell'Universita di Ferrara, DOI 10.1007/s11565-013-0176-x

[2] Hu, S. and Papageorgiou, N. S., Handbook of Multivalued Analysis, Vol. I and II, Kluwer Acad. Publ., Dordrecht, 1997 and 1999

[3] Petruşel, A., Multivalued weakly Picard operators and applications, Sci. Math. Jpn. 59 (2004), 169-202

[4] Petruşel, A. and Rus, I. A., The theory of a metric fixed point theorem for multivalued operators, Fixed Point Theory and its Applications, Yokohama Publ., Yokohama 2010, 161-175

[5] Petruşel, A. and Rus, I. A., The theory of a metric fixed point theorem for multivalued operators, Fixed Point Theory and its Applications, Yokohama Publ., Yokohama 2010, 161-175

[6] Rus, I. A., Petruşel, A. and Sîntămărian, A., Data dependence of the fixed point set of some multivalued weakly Picard operators, Nonlinear Anal., 52 (2003), 1947-1959

[7] Rus, I. A., Picard operators and applications, Sci. Math. Jpn., 58 (2003), 191-219

DEPARTMENT OF MATHEMATICS

BABEŞ-BOLYAI UNIVERSITY CLUJ-NAPOCA

KogĂLNiCEANU 1, 400084 Cluj-NAPOCA, ROMANIA

E-mail address: anca.oprea@math.ubbcluj.ro 